\title{
PROBLEMATIKA PERAN PERBANKAN SYARIAH DALAM REGULASI KELEMBAGAAN PENGELOLAAN ZAKAT
}

\author{
Aristoni \\ Institut Agama Islam Negeri (IAIN) Kudus \\ e-mail: toni_kurnia12@ymail.com
}

\begin{abstract}
The enactment of Law Number 23 Year 2011 on the Management of Zakat, making its own problems for sharia banking in helping the management of zakat. The role and function of sharia banking is not clear and weak. In addition to unclear, zakat management arrangements through sharia banking also pose legal political problems. This is because since the enactment of Law No. 23 of 2011 on the Management of Zakat is not accommodated expressly and concretely as an institution authorized as a manager of zakat. The vagueness of the role of sharia banking in zakat management regulation is a manifestation of vagueness and void of norms. Although the legal construction of banking roles and functions in accordance with Article 4 paragraph (2) of Law Number 21 Year 2008 concerning Sharia Banking is expanding, that is, syariah banking does not only carry out the activities of collecting funds and channeling public funds but can perform social functions as bait al-mall in collecting and distributing social funds of people as zakat. The enactment of the new zakat management law is expected to bring about big and positive changes, but in reality it seems not yet able to legally bind in applying the functions of zakat management.
\end{abstract}




\section{Aristoni}

Keywords: Zakat, Syariah Banking, Institutional Zakat Management

\section{Pendahuluan}

Ajaran zakat sesungguhnya menyimpan beberapa dimensi yang kompleks meliputi nilai privat-publik, vertikalhorizontal dan ukhrawi-duniawi. Nilai-nilai tersebut merupakan landasan pengembangan kehidupan kemasyarakatan yang komprehensif. Jika dimensi yang terkandung dalam ajaran zakat ini oleh umat islam baik zakat fitrah terlebih zakat mal yaitu mereka yang memiliki harta yang lebih, maka bukan tidak mungkin zakat akan menjadi sumber kekuatan yang sangat besar bagi pembangunan umat menuju kebangkitan kembali peradaban Islam (Sofwan Idris, 1997: 33).

Zakat merupakan pranata ekonomi di dalam agama Islam yang memiliki peran strategis dalam mewujudkan instrumen aturan guna mencapai tujuan zakat di antaranya zakat sebagai instrumen dalam mewujudkan kesejahteraan ekonomi mustahiq. Adapun untuk melegitimasi pentingnya zakat, hukum Islam menetapkan secara konkrit kedudukan hukum zakat sebagai salah satu rukun keislaman seseorang dan juga menjadi ketentuan ritual-transendental berbasis sosial yang wajib dilaksanakan bagi setiap muslim yang mampu. Pada hakikatnya, pentingnya kedudukan dan nilainilai zakat dalam kehidupan manusia merupakan bentuk kepatuhan terhadap ajaran Islam dan sekaligus merupakan penegasan konsekuensi kredo dari umat Islam kepada Tuhan-Nya. Oleh seba itu, zakat sebagai salah satu sarana ibadah vertikal yang mampu mengantarkan seseorang menjadi insan yang bertaqwa dan beriman. Adapun zakat sebagai entitas ekonomi tercermin dari nilai-nilai aksiologi kedudukan hukum dan fungsi sosial zakat (Ahmad Dakhoir, 2015: 18). 
Nilai-nilai aksiologi tersebut di atas, seyogyanya disambut dengan sistem pengelolaan zakat yang dapat menjamin kemanfaatan, mewujudkan keadilan ekonomi secara merata dan kapastian hukum. Di sini kehadiran perbankan syariah sebagai lembaga ekonomi Islam tentunya memiliki peran penting sebagai pintu gerbang transformasi nilai-nilai dan prinsip-prinsip ekonomi Islam melalui pelaksanaan zakat sebagai rukun Islam, dimana diharapkan mampu memperluas skala pelaksanaan sistem ekonomi Islam secara nasional dan tidak hanya terbatas pada lingkup dual bangking sistem, melainkan mampu sebagai penggerak ekonomi di Indonesia dalam wujud dual economic sistem. Adapun untuk mencapai harapan tersebut, perbankan syariah melalui fungsi sosial dan fungsi intermediasi dalam pengelolaan zakat sudah saatnya mampu menciptakan sebuah kerangka tujuan dan kebijakan legislasi yang mengarah pada ranah tujuan zakat, dimana sampai sekarang ini belum terkelola secara optimal oleh lembaga pengelola zakat baik BAZNAS maupun Lembaga Amil Zakat.

Perluasan terhadap fungsi sosial perbankan syariah sebagaimana yang dicita-citakan tersebut nampaknya mengalami permasalahan seiring Undang-Undang Nomor 21 Tahun 2008 tentang Perbankan Syariah, yang melegitasi keberadaan fungsi sosial perbankan syariah, akibatnya terjadinya kekosongan norma terkait fungsi sosial perbankan syariah itu sendiri dalam pengelolaan zakat. Di samping itu, dalam ketentuan Undang-Undang Nomor 23 Tahun 2011 tentang Pengelolaan Zakat, juga tidak menyebutkan secara tegas tentang peran perbankan syariah dalam pengelolaan zakat sehingga menjadikan peran dan fungsi sosial perbankan syariah menjadi lemah bahkan tidak diakui sama sekali.

Tidak diakuinya peran perbankan syariah dalam regulasi pengelolaan zakat merupakan bentuk kekosongan norma (vacuum of norm), dan kekosongan inilah yang 


\section{Aristoni}

menyebabkan perbankan syariah menjadi tidak memiliki kewenangan sepenuhnya dalam membantu pengelolaan zakat. Kajian ini mencoba merumuskan beberapa permasalahan dengan batasan masalah di antaranya adalah: pertama, bagaimana pengaturan kelembagan pengelolaan zakat di Indonesia? Kedua, apa saja problematika peran perbankan syariah dalam regulasi kelembagaan pengelolaan zakat?

\section{Pembahasan}

\section{Zakat dan Lembaga Perbankan Syariah}

Zakat adalah isim masdar dari kata zaka-yazku-zakah. Oleh karna kata dasar zakat adalah zaka yang berarti berkah, tumbuh, bersih, baik, dan bertambah. Dengan makna tersebut orang yang telah mengeluarkan zakat diharapkankan hati dan jiwannya akan menjadi bersih, sebagaimana firman Allah SWT dalam surat al-Taubah ayat 103.

Dari pengertian di atas, zakat selain hati dan jiwa bersih juga kekayaannya akan menjadi bersih pula. Di sini tergambar jelas bahwa zakat yang dikeluarkan oleh muzakki dapat membersihkan dan mensucikan hati manusia, tidak lagi memiliki sifat tercela terhadap harta seperti sifat rakus dan kikir. Menurut Hasbi al-Shiddiqi dan Abu Muhammad Ibnu Qutaibah sebagaimana dikutip Fakhruddin, ia mengatakan bahwa lafadz zakat diambil dari kata zakah yang berarti nama' yakni kesuburan dan penambahan. Dijelaskan pula syara' memakai kata tersebut untuk dua arti, yaitu pertama, dengan zakat diharapkan akan mendatangkan kesuburan pahala. Karenanya, harta yang dikeluarkan itu dinamakan zakat. Kedua, zakat merupakan sutau kenyataan jiwa suci dari kikir dan dosa (Fakhruddin, 2008: 13-14). 
Zakat sebagai salah satu rukun Islam sebagaimana rukun Islam lainnya (syahadat, shalat, puasa dan haji) tentunya didasarkan atas landasan hukum yang bersumber dari sumber utama hukum Islam yaitu Alquran dan Hadis. Dalam Alquran kata zakat dalam bentuk ma'rifat disebut sebanyak 30 (tiga puluh) kali, di antaranya 27 (dua puluh tujuh) kali disebutkan dalam satu ayat bersama shalat dan hanya satu kali disebutkan dalam konteks yang sama dengan shalat, akan tetapi tidak dalam satu ayat, yaitu dalam surat al-Mu'minun ayat 23 .

Apabila ditelusuri bahwa ketigapuluh kali zakat yang disebutkan tersebut, maka delapan kali disebutkan dalam surat yang turun di makkah (makkiyah) dan selebihnya diturunkan di madinah (madaniyyah). Selain perkataan zakat, terdapat istilah yang berkenaan dengan membelanjakan harta kekayaan yang dimiliki seseorang yaitu shadaqah. Kata Shadaqah memiliki arti benar, jujur, dan tepat janji. Kendati tujuan zakat dan shadaqah sama, akan tetapi keduanya memiliki perbedaan jika dilihat dalam sudut pandang hukum. Oleh karena itu, orang yang mempergunakan istilah sedekah wajib untuk zakat dan sedekah sunnah untuk shadaqah biasa.

Zakat dikatakan shadaqah karena tindakan itu akan menunjukkan kebenaran seorang hamba dalam beribadah dan melakukan ketaatan kepada Allah SWT. Sehingga dalam hal ini dapat ditarik benang merah bahwa zakat diwajibkan bagi orang kaya yang sudah memiliki tingkat kekayaan tertentu dan shadaqah dapat dilakukan siapa saja tergantung keikhlasan dan tingkat keimanan seseorang.

Di antara pijakan hukum disyariatkannya zakat dapat ditemukan dalam beberapa ayat Alquran dan Hadis. Salah satu ayat Alquran yang menerangkan pentingnya zakat yaitu terdapat dalam surat al-Baqarah ayat 110. Dan hadis yang diriwayatkan dari Umar bin Khattab, Rasulullah SAW 


\section{Aristoni}

bersabda: "Islam dibangun di atas lima pondasi pokok, yakni kesaksian bahwa tiada Tuhan selain Allah dan bahwa Muhammad itu utusan Alllah, mendirikan shalat, menunaikan zakat, melaksanakan haji, dan berpuasa bulan ramadhan".

Zakat merupakan suatu bentuk ibadah maaliyah ijtima'iyyah yang memiliki posisi sangat penting dan strategis bagi kesejahteraan umat. Pensyariatan zakat memberikan landasan bagi tumbuh dan berkembangnya kekuatan sosial ekonomi umat. Kandungan ajaran zakat ini memiliki dimensi yang sangat kompleks tidak hanya nilai-nilai ibadah, moral, spiritual, ukhrawi melainkan juga nilai-nilai ekonomi, sosial dan duniawai. Setiap bentuk kewajiban yang diperintahkan oleh Allah SWT kepada umat manusia bertujuan untuk membawa kebaikan bagi manusia itu sendiri. Begitu pula di dalam konsep ajaran zakat terdapat tujuan dan hikmah secara intrinsik dari ajaran tersebut.

Ajaran zakat memiliki potensi yang sangat besar terkait pembagian kemakmuran yang merata sehingga dapat menghilangkan rasa iri hati dan rasa tida puas di antara mereka yang kekurangan terhadap mereka yang berkelebihan, di antara si miskin dan si kaya. Di samping itu, melalui zakat terlebih dalam zakat harta tidak akan dimonopoli dalam penguasaan orang-orang kaya dan berada saja. Melalui zakat pula akan tercipta suatu kondisi rasa saling asih dan saling tolong menolong di antara si kaya dan si miskin, menambah keimanan, meningkatkan kesadaran beribadah, membina watak dan mental serta menghindari sikap kikir, sombong, dan perbuatan dhalim (Edi Bahtiar, 2009: 26-27).

\section{Lembaga Perbankan Syariah}

Dalam ketentuan Pasal 1 ayat (1) Undang-Undang Nomor 10 Tahun 1998 tentang perubahan Undang-Undang Nomor 7 Tahun 1992 tentang Perbankan, menyebutkan bahwa perbankan adalah segala sesuatu yang menyangkut 
tentang yang mencakup kelembagaan, kegiatan usaha, serta cara dan proses dalam melaksanakan kegiatan usahanya. Sehingga lembaga perbankan merupakan intisari dari sistem keuangan dari setiap negara. Dengan kata lain, bahwa bank merupakan lembaga keuangan yang menjadi tempat bagi orang perseorang, badan-badan usaha swasta, badan-badan usaha milik negara, bahkan lembaga-lembaga pemerintah menyimpan dana-dana miliknya. Melalui kegiatan perkreditan dan berbagai jasa yang diberikan. Pada dasarnya bank melayani kebutuhan, melancarkan sistem pembayaran bagi semua sektor perekonomian (Munir Fuady, 2007: 13).

Menurut perspektif hukum, yaitu Undang-Undang Nomor 14 Tahun 1967 tentang Pokok-Pokok Perbankan Pasal 1 huruf (a) menyebutkan bahwa bank adalah lembaga keuangan yang usaha pokoknya memberikan kredit dan jasajasa dalam lalu lintas pembayaran dan peredaran uang. Sementara itu, Undang-Undang Nomor 7 Tahun 1992 tentang perbankan Pasal 1 ayat (1) menyebutkan bahwa bank adalah badan usaha yang menghimpun dana dari masyarakat dalam bentuk simpanan, dan menyalurkannya kepada masyarakat dalam rangka meningkatkan taraf hidup rakyat banyak.

Sedangkan yang dimaksud dengan bank syariah adalah lembaga keuangan yang usaha pokoknya memberi layanan pembiayaan kredit dan jasa dalam lalu lintas pembayaran serta peredaran uang yang beroperasi disesuaikan dengan prinsip-prinsip syariah. Dengan kata lain, bank syariah merupakan bank yang beroperasi sesuai dengan prinsip-prinsip syariah Islam, mengacu pada ketentuan-ketentuan yang terdapat dalam Alquran dan Hadis. Dengan merujuk pada Alquran dan Hadis, maka diharapkan praktik bank syariah mampu menghindari aktivitas yang mengandung unsur riba dan segala macam bentuk praktik perbankan yang bertentangan dengan syariat Islam. 


\section{Aristoni}

Dalam Pasal 1 (1) Undang-Undang Nomor 21 Tahun 2008 tentang Perbankan Syariah, menyebutkan bahwa perbankan syariah adalah segala sesuatu yang menyangkut tentang bank syariah dan unit usaha syariah yang mencakup kelembagan, kegiatan usaha, serta tata cara dan proses dalam melaksanakan kegiatan usahanya. Hal tersebut menegaskan bahwa segala hal mengenai perbankan syariah baik yang menyangkat kelembagaan, kegiatan usaha, maupun prosesnya dilakukan berdasakan Undang-Undang yang baru. Jelas ini mengindisikan bahwa pada undang-undang sebelumnya yang mengatakan bahwa setiap kegiatan usahausaha bank berdasarkan prinsip syariah dikatakan sebagai kegiatan yang berdasarkan prinsip bagi hasil mulai ditinggalkan. Sebab hal ini dikarenakan dunia perbankan Indonesia sudah mulai mengenal dan mengakui perbankan syariah dan menerpakan dual banking system, yaitu perbankan konvensional dan perbankan syariah.

Kendati demikian, terdapat perbedaan antara bank konvensioal dan bank syariah dalam beberapa hal. Dimana bank konvensional memakai sistem bunga, sedangkan pada bank syariah tidak melaksanakan sistem bunga dalam seluruh kegiatannya. Tentunya hal ini memiliki implikasi yang sangat dalam dan sangat berpengaruh pada aspek opersional dan produk yang dikembangkan oleh bank syariah. Bank syariah lebih menekankan sistem kerja dan kemitraaan, kebersamaan utamanya kesiapan semua pihak untuk berbagi termasuk dalam hal-hal keuntungan dan kerugian (Imamul Arifin, 2007: 14).

\section{Perbankan Syariah sebagai Pengelola Zakat (Bait Al-Mal)}

Berdasarkan Undang-Undang Nomor 21 Tahun 2008 tentang Perbankan Syariah, bahwa bank syariah selain menjadi lembaga/perusahaan yang besifat komersial yang mana dalam hal ini menghimpun dan menyalurkan dana dengan tujuan memperoleh keuntungan, bank syariah juga 
bertindak sebagai lembaga sosial (bait al-mal) yang menghimpun dana seperti zakat, infak, dan sedekah untuk kemudian menyalurkannya kepada yang berhak. Dengan ketentuan penyaluran dananya yang sudah ditentukan yaitu delapan asnaf (golongan). Dengan merujuk Undang-Undang tersebut memberikan pemahaman kapada kita bahwa konstruksi hukum fungsi perbankan syariah mengalami perluasan fungsi (Muhammad Syafi'i Antonio, 2001: 65).

Perluasan fungsi perbankan syariah termuat dalam Pasal 4 ayat (2) Undang-Undang Nomor 21 Tahun 2008 tentang Perbankan Syariah. Secara historis, perluasan fungsi perbankan syariah dalam menghimpun dan menyalurkan zakat sesungguhnya dilatarbelakangi menguatnya respon masyarakat terhadap perbankan syariah dan tumbuhnya market share ekonomi pada sektor lembaga keuangan berbasis syariah. Perluasan fungsi sosial perbankan syariah dalam mengelola zakat merupakan pelaksanaan lembaga ekonomi Islam untuk mempermudah uatamnya nasabah perbankan syariah dalam menunaikan ibadah zakat. Adapun Pasal 4 ayat (2) tentunya memberikan konstruksi hukum kelembagaan pengelolaan zakat di Indonesia bertambah satu lagi, yakni melalui pengelolaan zakat berkonsep perusahaan. Namun sejak tahun 2011, kelembagaan pengelolaan zakat sebagaimana yang diamanahkan dalam Undang-Undang Nomor 38 Tahun 1999 tentang Pengelolaan Zakat dan Undang-Undang Nomor 21 Tahun 2008 tentang Perbankan Syariah dikembalikan kepada fungsi negara sebagai pemegang mandat dalam mewujudkan keadilan sosial di bidang pengelolaan zakat (Ahmad Dhakoir, 2015: 43).

Akan tetapi, pengelolaan zakat di Indonesia sebagaimana yang telah diamanahkan dalam UndangUndang Nomor 21 Tahun 2008, tampaknya belum memperlihatkan hasil yang maksimal, sehingga dalam hal ini mengalami persoalan hukum tersendiri ketika dihadapkan pada keberdaaan dan peran lembaga zakat sebagaimana 


\section{Aristoni}

menguatnya respon masyarakat muslim. Untuk menjembatani persoalan hukum tersebut, maka langkah yang dilakukan adalah melalui pendekatan teori hukum responsif. Hukum responsif merupakan teori tentang profil hukum yang dibutuhkan dalam masa transisi (Rachmad Safa'at, 2013: 31).

Hukum responsif, sebagimana dikutip Ahmad Dhakoir pada dasarnya mengandalkan dua doktrin utama yaitu pertama, hukum harus fungsional, pragmatik, bertujuan dan rasional. Kedua, kompetensi menjadi patokan evaluasi terhadap semua pelaksanaan hukum. Karena kompetensi sebagai tujuan berfungsi sebagai norma kritik, sehingga tatanan hukum responsif menitikberatkan pada beberapa hal yaitu di antaranya: keadilan substantif sebagai dasar legitimasi hukum, peraturan merupakan su-ordinasi dari prinsip dan kebijakan, petimbangan hukum harus mengarah pada tujuan dan akibat bagi kemaslahatan masyarakat, penggunaan diskresi sangat dianjurkan dalam pengambilan keputusan hukum dengan tetap berorientasi pada tujuan, memupuk sistem kewajiban sebagai ganti sistem paksa, moralitas kerjasama sebagai prinsip moral dalam menjalankan hukum, kekuasaaan didayagunakan untuk mendukung vitalitas hukum dalam melayani masyarakat, penolakan terhadap hukum harus dilihat sebagai gugatan terhadap legitimasi hukum, akses partisipasi publik dibuka lebar dalam rangka integrasi advokasi hukum dan sosial.

Dari beberapa unsur-unsur hukum responsif di atas, sudah seharusnya kelembagaan pengelolaa zakat di Indonesia mampu mengakomodir elemen-elemen tesebut. Salah satunya yaitu melaksanakan pengelolaan zakat yang bersifat partisipatif dan mengarah pada keadilan substantif.

Pengaturan Kelembagaan Pengelolaan Zakat 
Salah satu tujuan hukum dibidang perekonomian ialah mewujudkan keadilan ekonomi terhadap kelompok masyarakat berekonomi lemah. Indonesia sebagai negara hukum yang menjunjung tinggi hak asasi manusia dibidang perekonomian berkewajiban mendorong dan memberdayakan masyarakat berekonomi lemah terutama dalam memenuhi hak-hak kebutuhan hidup. Tugas dan peran negara Indonesia melalui pemerintah dalam rangka mewujudkan keadilan ekonomi kaum fakir miskin tertuang dalam Pasal 34 UUD 1945.

Salah satu sumber daya ekonomi yang tidak boleh dipandang sebelah mata yang berpotensi membantu pemerintah dalam menanggulangi dan mengentaskan masalah ekonomi terutama kefakiran dan kemiskinan yaitu bersumber dari dana-dana sosial berbasis keagamaan seperti shadaqah, infak, hibah, wakaf, dan hadiah. Selain itu sumber dana sosial keagamaan yang bersifat anjuran, negara juga dapat mengelola sumber dana ekonomi keagamaan yang bersifat wajib seperti zakat fitra dan zakat harta.

Zakat sebagai salah satu sumber daya ekonomi dan instrumen penanggulangan masalah perekonomian berbasis prinsip syariah, sudah barang tentu membutuhkan dukungan pemerintah dan pelembagaan pengeloaan yang baik. Indonesia sebagai negara hukum, menempatkan zakat sebagai instrumen norma hukum berdasarkan Pancasila dan UUD NRI 1945. Legislasi kewajiban zakat bagi umat Islam yang mampu di Indonesia tercermin dari perwujudan sila pertama yaitu Ketuhanan Yang Maha Esa dan Pasal 29 UUD NRI 1945. Guna untuk mencapai tujua zakat secara berhasil guna dan berdayaguna, maka suatu organisasi pengelolaan zakat perlu menerapkan asas-asas tertentu dalam operasional kelembagaan. Adapun beberapa prinsip dasar yang menjadi asas dalam kelembagaan organisasi zakat ialah asas kemaslahatan umum, asas pembagian tugas, asas fungsionalisasi, asas koordinasi, dan asas kesinambungan. 


\section{Aristoni}

Di era reformasi, pemerintah berupaya untuk menyempurnakan sistem pengelolaan zakat di tanah air dengan harapan agar potensi zakat dapat dimanfaatkan untuk memperbaiki kondisi sosial ekonomi bangsa yang terpuruk akibat resesi ekonomi dunia dan krisis multi dimensi yang melanda Indonesia. Untuk itulah pada tahun 1999, pemerintah bersama Dewan Perwakilan Rakyat telah menerbitkan Undang-Undang Nomor 38 Tahun 1999 tentang Pengelolaan Zakat, yang kemudian diikuti dengan dikeluarkannya Keputusan Menteri Agama Nomor 581 tahun 1999 tentang Pelaksanaan Undang-Undang Nomor 38 Tahun 1999 dan Keputusan Direktur Jendral Bimas Islam dan Urusan Haji Nomor D-291 Tahun 2001 tentang Pedoman Teknis Pengelolaan Zakat.

Sejak dikeluarkannya Undang-Undang Nomor 38 Tahun 1999 tentang Pengelolaan Zakat, maka pengelolaan zakat dilakukan oleh Badan Amil Zakat (BAZ) yang dibentuk oleh pemerintah yang terdiri dari masyarakat dan unsur pemerintah untuk tingkat kewilayahan dan Lembaga Amil Zakat (LAZ) yang dibentuk dan dikelola oleh masyarakat yang terhimpun dalam berbagai organisasi kemasyarakatan Islam, yayasan, dan lembaga lainnya. Dalam ketentuan Undang-Undang tersebut dijelaskan bahwa prinsip pengelolaan zakat secara profesional dan bertanggungjawab yang dilakukan oleh masyarakat bersama pemerintah (Fakhruddin, 2008: 247-248).

Kehadiran Undang-Undang Nomor 38 Tahun 1999 tentang Pengelolaan Zakat, pada dasarnya menjadi landasan hukum bagi pelaksanaan zakat di Indonesia, meskipun disadari bahwa di dalam pasal-pasalnya masih terdapat kelemahan dan kekurangan misalnya tidak adanya sanksi bagi muzakki yang tidak mau atau enggan menunaikan zakat hartanya dan sebagainya. Sebagai suatu konsekuensi dari Undang-Undang Zakat, pemerintah pusat sampai pemerintah daerah wajib memfasilitasi terbentuknya 
lembaga pengelola zakat, yaitu Badan Amil Zakat Nasional (BAZNAS) untuk tingkat pusat dan Badan Amil Zakat Daerah (BAZDA) untuk tingkat daerah. Perlu diketahui bahwa BAZNAS dibentuk berdasarkan Keputusan Presiden Nomor 8/2001, tanggal 17 Januari 2001. Sesuai dengan peraturan Perundang-undang yang ada, hubungan BAZNAS dengan Badan Amil Zakat yang lain bersifat koordinatif, konsultatif, dan informatif. BAZNAS dan BAZDA-BAZDA bekerjasama dengan lembaga amil zakat (LAZ) baik yang bersifat nasional maupun daerah, hal ini dimaksudkan agar dapat terbangun sebuah sistem zakat nasional yang baku dan dapat diaplikasikan oleh semua pengelola zakat.

Sehubungan dengan menjalankan program kerjanya, dalam hal ini BAZNAS menggunakan konsep sinergi, artinya yaitu untuk pengumpulan zakat maupun infak dan shadaqah menggunakan hubungan kerjasama dengan Unit Pengumpul Zakat (UPZ) di departemen-departemen, BUMN, Konjen dan Lembaga Amil Zakat lainnya. Pola kerjasama ini disebut dengan UPZ Mitra BAZNAS. Sedangkan untuk penyaluranya, BAZNAS juga menggunakan pola sinergi dengan Lembaga Amil Zakat lainnya yang disebut sebagai Unit Salur Zakat (USZ) Mitra BAZNAS.

Seiring waktu yang terus berjalan, semangat untuk mengelola zakat masih terus bergulir. Pada tahun 2011 pemerintah mengamandemen Undang-Undang Nomor 38 Tahun 1999 tentang Pengelolaan Zakat dengan UndangUndang Nomor 23 Tahun 2011 tentang Pengelolaan Zakat. melalui Undang-undang tersebut, persoalan dualisme kelembagaan pengelolaan zakat terjawab sudah. Sesuai Pasal 1 ayat (7) Undang-Undang Nomor 23 Tahun 2011 tentang Pengelolaan Zakat, bahwa BAZNAS adalah lembaga yang bertugas melakukan pengelolaan zakat secara nasional sedangkan LAZ hanya bertugas membantu BAZNAS dalam pengumpulan, pendistribusian, dan pendayagunaan zakat. kendati masalah kelembagaan sudah selesai dengan 


\section{Aristoni}

menepatkan tugas pengelolaan zakat nasional terpusat pada BAZNAS namun bukan berarti masalah kelembagaan pengelolaan zakat usai, sebab saat ini masih banyak Lembaga Amil Zakat yang melaksanakan pengelolaan zakat.

Secara aspek kelembagaan, Organisasi Pengelola Zakat (OPZ) beberapa tahun terakhir menjadi organisasi yang mengalami perkembangan pesat baik secara kuantitas yaitu jumlah yang semakin banyak dan beragam maupun secara kualitas kelembagaan yang semakin baik. Hal tersebut disebabkan karena oleh kepercayaan masyarakat kepada Organisasi Pengelolaan Zakat (OPZ) semakin terlihat yaitu mempercayakan atau menitipkan dana zakatnya kepada OPZ (Sri Farida dkk, 2017: 60). Keberadaan beragamnya kelembagaan pengelolaan zakat setelah berlakunya UndangUndang Nomor 23 Tahun 2011 tentang Pengelolaan Zakat, sebenarnya menganut asas terintegrasi. Asas terintegrasi mengawal pengelolan zakat secara tepusat melalui hierarki BAZNAS sebagai pengelola zakat dalam skala nasional dan BAZDA sebagai pengelola zakat dalam lingkup wilayah Provinsi, Kota, Kabupaten hingga Kecamatan. Pembentukan undang-undang baru mengenai pengelolaan ini patut kita apesiasi. Langkah ini merupakan bukti peran dan keberpihakan negara dalam upaya mewujudkan keadilan ekonomi melalui instrumen keagamaan seperti zakat.

\section{Problematika Peran Perbankan Syariah dalam Regulasi Kelembagaan Pengelolaan Zakat}

Pada hakikatnya, tujuan dibentuknya organisasi pengelola zakatnya sebenarnya adalah untuk meningkatkan seluruh unsur dalam pengelolaan zakat. Salah satu sasaran zakat yang dapat menambah in come zakat yaitu para nasabah di lembaga-lembaga keuangan. Inilah yang mendorong pemerintah turut berupaya menjaring dana zakat yang bersumber dari nasabah-nasabah lembaga keuangan seperti perbankan. Hal ini juga yang menyebabkan pemerintah pada 
tahun 1999 memerintahkan agar Badan Amil Zakat (BAZ) dapat bekerjasama dengan perbankan dalam rangka menjaring meski hanya dalam zakat harta muzakki pada lingkup nasabah bank tersebut.

Secara yuridis, peran dan fungsi lembaga keuangan seperti perbankan syariah dalam sistem pengelolaan zakat tertuang dalam Pasal 4 ayat (2) Undang-Undang Nomor 21 Tahun 2008 tentang Perbankan Syariah, yang menyebutkan bahwa bank syariah dan unit usaha syariah dapat menjalankan fungsi sosial dalam bentuk lembaga bait al-mal, yaitu menerima dana yang berasal dari zakat, infak, shadaqah, hibah, atau dana sosial lainnya dan menyalurkannya kepada organisasi pengelola zakat. Pada dasarnya fungsi utama perbankan yaitu menjalankan tugas penghimpunan dan penyaluran dana kepada pihak yang membutuhkan dana. Adapun fungsi penghimpunan dan penyaluran dana oleh bank merupakan amanah Undangundang. Fungsi bank ini disebut fungsi intermediasi. Fungsi bank sebagai lembaga intermediasi sebagaimana tertuang dalam Pasal 1 ayat (2) Undang-Undang Nomor 10 Tahun 1998 tentang perubahan Undang-Undang Nomor 7 Tahun 1992 tentang Perbankan. Fungsi intermediasi bank juga dapat diartikan sebagai kegiatan mengalirkan dana dari nasabah yang memiliki kelebihan dana (savers/deposan) sebagai penabung ke nasabah yang memerlukan dana (borrowers) sebagai peminjam (Triandaru Sigit dan Totok B, 2008: 12).

Fungsi bank sebagai lembaga intermediasi sebagaimana yang telah dijelaskan di atas, juga menjadi kewajiban perbankan syariah. Ketentuan tersebut di atur dalam Pasal 4 ayat (1) Undang Nomor 21 Tahun 2008 tentang Perbankan Syariah, bahwa perbankan syariah baik bank syariah maupun unit usaha dalam perbankan konvensional wajib menjalankan fungsi menghimpun dan menyalurkan dana masyarakat (Artesa Ade dan Edia Handiman, 2006: 11). 


\section{Aristoni}

Sebagai entitas bisnis, perbankan syariah tidak hanya melakukan kegiatan bisnis sebagaimana fungsi intermediasi, melainkan juga melakukan kegiatan-kegiatan sosial. Peran dan fungsi sosial perbankan syariah yaitu menghimpun dana-dana sosial umat seperti zakat, infaq, shadaqah, hibah, dan wakaf dan menyalurkannya kepada organisasi pengelolaan zakat yang diperuntukkan sebagai tujuan pengelolaan zakat di dalam Undang-Undang Nomor 23 Tahun 2011 tentang Pengelolaan Zakat. Melihat berbagai tantangan dalam pengelolaan keuangan termasuk harta zakat, perluasan fungsi perbankan syariah memiliki peran yang strategis dan dapat menjadi alternatif model dalam membantu menjaring dan mengelola dana zakat yang tepat guna, terpadu, modern dan lebih rapi. Akan tetapi, pentingnya kiprah perbankan syariah dalam membantu pengelolaan zakat justru tidak diakui secara eksplisit di dalam Undang-Undang Nomor 23 Tahun 2011 tentang Pengelolaan Zakat. Undang-Undang Pengelolaan Zakat tidak mengatur secara tegas dan kongkrit tentang otoritas perbankan syariah dalam menjalankan fungsi sosialnya dibidang pengelolaan zakat. Tentunya hal ini menjadi problem yuridis tersendiri bagi perbankan syariah.

Problem yuridis ini dapat kita lihat dari ketentuan Pasal 7 ayat (2) dalam Undang-Undang Nomor 23 Tahun 2011 tentang Pengelolaan Zakat, yang menyebutkan bahwa dalam melaksanakan tugas dan fungsinya, BAZNAS dapat bekerjasama dengan pihak terkait sesuai dengan ketentuan peraturan Perundang-undangan.

Adapun pihak terkait yang dimaksud dalam Pasal 7 ayat (2) tersebut adalah kementerian, BUMN dan lembaga luar negeri. Perbankan syariah sebagai bagian dari BUMN memang dimungkinkan dapat bekerjasama dengan BAZNAS. Akan tetapi, ketika Pasal 7 ayat (2) UndangUndang Nomor 23 Tahun 2011 tentang Pengelolaan Zakat tidak menyebutkan kerjasama BAZNAS secara kongkrit ke 
dalam redaksi ketentuan tersebut, sehingga menimbulkan ketidakjelasan bentuk kerjasama dalam pengelolaan zakat dan kekosongan norma terkait fungsi sosial perbankan syariah dalam membantu pengelolaan zakat, terlebih dalam ketentuan Pasal 13 ayat (2) Keputusan Dirjen Bimbingan Masyarakat Islam dan Urusan Haji Nomor D/291 Tahun 2000 tentang Pedoman Teknis Pengelolaan Zakat, menyebutkan bahwa BAZNAS dapat bekerjasama dengan semua bank, atau dengan kata lain bukan hanya dengan perbankan syariah adalah tidak sesuai dengan asas-asas dalam Pasal 4 ayat (2) Undang-Undang Nomor 23 Tahun 2011 tentang Pengelolaan Zakat, dan asas-asas dalam pengelolaan zakat sebagamana tercermin dalam Pasal 2 Undang-Undang Nomor 23 Tahun 2011 tentang Pengelolaan Zakat. beragkat dari sinilah sehingga menimbulkan berbagai masalah normatif dalam regulasi pengeloaan zakat di Indonesia.

Menurut Ahmad Dakhoir, kekosongan norma fungsi sosial perbankan syariah terlihat jelas dalam 2 (dua) substansi. Substansi pertama, bahwa fungsi sosial perbankan syariah sebagai lembaga bait al-mal dalam ketentuan pasal 4 ayat (2) Undang-Undang Nomor 21 Tahun 2008 tentang Perbankan Syariah, tidak diakui sebagai lembaga penerima zakat sebagaimana dalam Pasal 7 ayat (2) Undang-Undang Nomor 23 Tahun 2011 tentang Pengelolaan Zakat. hal ini bertolak dari undang-undang yang lama yaitu Pasal 12 ayat (2) Undang-Undang Nomor 38 Tahun 1999 tentang Pengelolaan Zakat mengakui keberadaan perbankan dalam membantu pengumpulan zakat, meskipun dalam hal ini hanya dalam zakat harta dan bank umum konvensional. Substansi kedua, bahwa kekosongan norma terlihat belum diaturnya peraturan-peraturan pelaksana yang diguanakn sebagai pedoman teknis pengelolaan zakat melalui perbankan syariah (Ahmad Dakhoir, 2015: 19). 


\section{Aristoni}

Lebih lanjut masalah kelembagaan pengelolaan zakat yang berintegrasi melalui fungsi sosial perbankan syariah menjadikan berbagai problem teoretis. Beberapa probem teoretis tersebut yaitu pertama, terdapat pertentangan antara teori dan konsep kelembagaan dalam lembaga perbankan. Perbankan syariah sebagai lembaga berbadan hukum perusahaan tentu sarat dengan masalah-masalah bisnis, satu sisi perbankan syariah merupakan entitas bisnis berbasis profit, di sisi lain perbankan syariah menjalankan fungsi sosial yang notabene bukan berorientasi pada peran sosial yang berseberangan dengan konsep-konsep perusahaan pada umumnya. Kedua, pengaturan kelembagaan pengelolaan zakat yang belum terintegrasi melalui perbankan syariah menjadikan pertentangan asas kesesuaian syariah dalam pengelolaan zakat. adapun pelaksanaan pengelolaan zakat yang belum terintegrasi secara sosial dapat memicu konflik horizontal, sebagaimana kenyataan dilapangan memperlihatkan bahwa sistem pengelolaan zakat masih belum mampu menggeser mustahiq menjadi muzakki dari tahun ke tahun.

Untuk mengatasi berbagai problematika tersebut di atas, diperlukan peraturan-peraturan pelaksanaan yang baru sebagai turunan dari Undang-Undang Nomor 23 Tahun 2011 tentang Pengelolaan Zakat, terlebih terhadap Pasal 7 ayat (2) Undang-Undang Nomor 23 Tahun 2011 tentang Pengelolaan Zakat dan Pasal 13 ayat (2) Keputusan Dirjen Bimbingan Masyarakat Islam Dan Urusan Haji Nomor D/291 Tahun 2000 tentang Pedoman Teknis Pengelolaan Zakat, sudah seharusnya dilakukan perbaruan dan disesuaikan dengan peran dan fungsi sosial perbankan syariah, sehingga tidak terjadi kekosongan norma dalam pengaturan fungsi sosial perbankan syariah. Sebab kekosongan dalam norma tersebut dalam sistem pengelolaan zakat terlebih dalam UndangUndang Nomor 23 Tahun 2011 tentang Pengelolaan Zakat 


\section{Problematika Peran Perbankan Syariah ...}

dapat menimbulkan problematika utamanya pada ranah yuridis.

\section{Simpulan}

Berangkat dari uraian pembahasan di atas, maka dapat disimpulkan bahwa perbankan syaraiah sebagai suatu entitas bisnis, tidak hanya melakukan kegiatan bisnis an sich sebagaimana fungsi intermediasi, melainkan perbankan syaraiah turut aktif dalam melakukan kegiatan-kegiatan sosial. Peran dan fungsi sosial perbankan syariah yaitu menghimpun dana-dana sosial umat seperti zakat, infak, shadaqah, hibah, dan wakaf, dan menyalurkannya kepada organisasi atau Lembaga Amil Zakat untuk kemaslahatan umum. Peran dan fungsi sosial perbankan syariah merupakan kegiatan sosial yang diharapkan dapat mewujudkan kesejahteraan masyarakat dan menjadi instrumen penanggulangan kemiskinan melalui pengelolaan sumber dana seperti infak, shadaqah, hibah, wakaf dan lainlain terutama pengelolaan dana zakat yang sangat potensial dengan pengelolaan yang lebih akuntabel dan profesinal.

Seiring berlakunya Undang-Undang Nomor 23 Tahun 2011 tentang Pengelolaan Zakat perubahan atas UndangUndang Nomor 38 Tahun 1999 tentang Pengelolaan Zakat, peran dan fungsi perbankan syariah dihadapkan berbagai problematika terutama pada ranah yuridis, dimana dalam ketentuan Pasal 7 ayat (2) Undang-Undang Nomor 23 Tahun 2011 tentang Pengelolaan Zakat tidak menyebut kerjasama BAZNAS dengan perbankan syariah secara kongkrit ke dalam redaksi ketentuan pasal tersebut, sehingga menimbulkan ketidakjelasan bentuk kerjasama dalam pengelolaan zakat dan kekosongan norma terkait fungsi sosial perbankan syariah dalam membantu pengelolaan zakat. maka, sebagai upaya dalam mengatasi problem yuridis tersebut perlu dilakukan perbaruan dan disesuaikan 


\section{Aristoni}

dengan peran dan fungsi sosial perbankan syariah, sehingga tidak terjadi kekosongan norma dalam pengaturan fungsi sosial perbankan syariah.

\section{Daftar Pustaka}

A. Jazuli dan Yadi Yanuari, Lembaga-Lembaga Perekonomian Umat (Sebuah Pengenalan), Rajawali Press, Jakarta, 2001.

Artesa Ade dan Edia Handiman, Bank dan Lembaga Keuangan Bukan Bank, Indeks, Jakarta, 2006.

Ahmad Dakhoir, Hukum Zakat; Pengaturan dan Integrasi Kelembagaan Pengelolaan Zakat Dengan Fungsi Lembaga Perbankan, Aswaja Pressindo (Members Of Laksbang Group) Perwakilan Jawa Timur Dan Indonesia Timur, Surabaya, 2015.

Didin Hafidhuddin, Zakat Dalam Perekonomian Modern, Gema Insani Press, Jakarta, 2004.

Edi Bahtiar, Ke Arah Produktivitas Zakat Membangun Strategi Zakat Berpresfektif Keadilan, Idea Press, Yogyakarta, 2009.

Fakhruddin, Fiqih dan Manajemen Zakat di Indonesia, UIN Malang Press, Malang, 2008.

Imamul Arifin, Membuka Cakrawala Ekonomi, Setia Purna Inves, Jakarta, 2007.

Munir Fuady, Hukum Perbankan Modern Buku Kesatu, Citra Aditya, Bandung, 2007.

Rachmad Safa'at, Rekonstruksi Politik Hukum Pangan: Dari Ketahanan Pangan Ke Kedaulatan Pangan, Universitas Brawijaya Press, Malang, 2013. 


\section{Problematika Peran Perbankan Syariah ...}

Sofwan Idris, Gerakan Zakat Dalam Pemberdayaan Ekonomi Umat Pendekatan Transformatif, Cet. 1, Citra Putra Bangsa, Jakarta, 1997.

Sudirman, Zakat Dalam Pusaran Arus Modernitas, UIN Malang Press, Malang, 2007.

Sri Fadilah dkk, Organisasi Pengelola Zakat (OPZ): Deskripsi Pengelolaan Zakat Dari Aspek Lembaga Zakat, Kajian Akuntasi, Universitas Islam Bandung, Vol. 18 No. 1 September 2017.

Triandaru Sigit dan Totok B, Bank dan Lembaga Keuangan Lainnya, Salemba, Jakarta, 2008.

Tim Penyusun, Ensiklopedi Hukum Islam, Jilid VI, Ichtiyar Baru Van Hoeve, Jakarta, 2001.

Wahbah al-Zuhaili, al-Figh al-Islamiy wa Adillatuh, Jilid III, tth. 